\title{
Reporting from the realm of the absurd: Rethinking space in a neoliberal world
}

\author{
Abraham P. DeLeon ${ }^{1}$
}

Space is a central feature of contemporary society and capitalism is a uniquely spatial affair. As critical theories have tried to understand the implications of this reality over the past few decades, Marxism and "poststructural" theories have integrated space into their analysis, focusing on how capitalism has shaped it, the ways in which power/knowledge emerge through spatial realities and the coercive and disciplinary ways in which it shapes our bodies and subjectivities. Anarchist theory has also dealt with space, but has been inadequate in dealing with its full implications, limiting its potential in building a nuanced and sophisticated resistance. In this article, the author explores the politics of space through a neo-Marxist, "poststructuralist" and anarchist lens, arguing that these traditions need to be combined to rethink space and build new forms of subjectivities. In particular, the author focuses on two archetypes (the nomad and the vagabond) as examples that defy ideological and spatial constraints, exhibiting a uniquely anarchist subjectivity. [Article copies available for a fee from The Transformative Studies Institute. E-mail address: journal@transformativestudies.org

Website: http://www.transformativestudies.org (C2010 by The Transformative Studies Institute. All rights reserved.]

KEYWORDS: Space and Place, Anarchist Theory, Postmodernism, Marxism, Subjectivity.

\footnotetext{
${ }^{1}$ Abraham P. DeLeon, Ph.D., is an assistant professor at the University of Texas at San Antonio in the Department of Educational Leadership and Policy Studies. His critiques are grounded in critical and radical social theories and have been influenced by cultural studies, anarchism, critical pedagogy, critical discourse studies, and postcolonial theory. He has articles that appear in Educational Studies, Critical Education and forthcoming in Equity \& Excellence in Education and has authored book chapters in various edited collections. He also was a member of the editorial collective that produced Contemporary Anarchist Studies: An introductory anthology of anarchy in the academy (Routledge, 2009) and has edited a forthcoming book with E. Wayne Ross, Critical theories, radical pedagogies, and social education: Towards new perspectives for the social studies (Sense Publishers, Forthcoming). Address correspondence to: Abraham P. DeLeon, Department of Educational Leadership \& Policy Studies, One UTSA Circle, San Antonio, TX 78249.
} 